\title{
Echoes and Shadows: A Phenomenological Reconsideration of Plato's Cave Allegory
}

\author{
Edvin Østergaard, Professor, Section for Learning and Teacher Education, Faculty for \\ Science and Technology, Norwegian University of Life Sciences \\ Email:edvin.ostergaard@nmbu.no
}

\begin{abstract}
In the cave allegory, Plato illustrates his theory of ideas by showing that the world man senses and tries to understand, actually only is a dim representation of the real world. We know the allegory for its light and shadow; however, there is also sound and echo in the cave. In this article, I discuss whether the narrative of the prisoners in the cave is in tune with an audial experience and whether an allegory led by sound corresponds to the one led by sight. I start with a phenomenological analysis of the cave as a place of sound. After that, I elaborate on the training of attentive listening skills and its ramifications for pedagogical practice. I conclude that there are profound differences between seeing and listening and that sound reveals different aspects of "the real" compared to sight. The significance of Plato's cave allegory should be evaluated in relation to modern, scientific thought characterised by a visual-spatial language. With support of this allegory, the light-shadow polarity has become the Urbild of represented reality. At the same time, a visually oriented culture of ideas repeatedly confirms Plato's cave allegory as its central metaphor. Finally, an elaboration on the sounds in the cave proves to be fruitful in an educational sense: The comparison of sound and sight sharpens the differences and complementarities of audial and visual experiences.
\end{abstract}

Keywords: Attentive listening, cave allegory, phenomenon-based science education

\section{Introduction}

Among Plato's dialogues, the allegory of the cave holds a unique position. The narrative of the prisoners watching the shadows on the cave wall is well-known from philosophy textbooks and perhaps the most famous of Plato's allegories and parables. The text is found in the Republic, Book VII, and is written as a dialogue between Plato's brother Glaucon and his mentor Socrates (Plato, 1992; 1993). The allegory illustrates Plato's theory of ideas by showing that the world man senses and tries to understand, actually only is a dim representation of the real world: the world of ideas. The allegory is known for its light and shadow; however, there is also sound in the cave, as David Espinet (2016) made me aware of in his analysis of the significance of listening in Martin Heidegger's philosophy. I read Plato's text again with an open ear, as if I would be in the cave. The experience made me ask: Is the story of the people in the cave in tune with an audial experience and does an allegory led by sound correspond to the one led by sight? 
With a background in both life sciences, science teacher education, and musical composition, I am especially interested in applying musical listening to everyday, lived experiences. With its rich tradition of close listening and aural attendance, music is much more than mere pleasure and amusement. For me, the act of listening is essentially a continuous practice of paying attention. I base my arguments on an elaboration of the cave as a place for attentive listening. I reflect on questions emerging after having paid careful attention to the sounds in the cave that Plato uses as a context for his allegory.

As I will argue in this article, there is a need to reconsider the value of audial experience in education, especially in science education, my field of teaching and research. I am especially interested in exploring the power of listening as a pre-conceptual experience. Inspired by phenomenology, I start by entering the cave and, just like Plato hints at, employing my ears. In the second part, I turn to a discussion of the relation between the real and representations of the real in the span between visual and audial experience. Finally, in the third part, I discuss some educational questions, which are drawn from the sonic interpretation of the cave allegory, especially related to phenomenon-based science education.

\section{Being in the Cave, Listening}

Socrates invites Glaucon to take part in a thought experiment: Imagine a group of people "living in a cavernous cell down under the ground" (Plato, 1993, p. 240). The persons are described as prisoners; they are chained to the ground, and their heads are fixed in such a manner that they can only look straight ahead, to the back wall of the cave. There are other persons in the cave as well, carrying all sort of things, moving behind the prisoners along a low wall and between the prisoners and a firelight. The prisoners can merely watch the shadows of the carriers, not the persons themselves. Socrates proceeds by describing how one of the prisoners is freed and "suddenly made to stand up, to turn his head and walk, and to look towards the firelight" (p. 241). The person then continues "up the rough, steep slope" (p. 242) and into the sunlight. After having adjusted his sight to the intense light and the new surroundings, he now experiences the meaning and beauty of the world and the sun as the source of all life. If, however, he returns to the cave and tells the other prisoners about his discoveries, they would think that the strong sunlight has ruined his eyesight and "that it wasn't even worth trying to get up there" (p. 243). And, Socrates further asks, wouldn't the prisoners "grab hold of anyone who tried to set them free and take them up there and kill him?" (p. 243).

Plato shows that for the prisoners, the shadows appear as the actual reality. He explains how philosophers are like the prisoner who escapes from the cave and eventually comes to understand that the shadows are not the reality at all. Whereas the prison cave is likened to the "region which is accessible to sight" (p. 243) and the firelight to the light of the sun, the prisoner's upward journey is "the mind's ascent to the intelligible realm" (p. 244). Plato argues that philosophers perceive the true form of reality rather than the reduced reality, symbolized by the moving shadows that the fettered prisoners see.

What I would like to dwell at here, is the cave as a place of sounds. We know the allegory for its visual language. However, twice we find an audial language as well. Socrates talks about the people moving behind the prisoners and the sounds they make; "some of the people talk as they carry these objects along, while others are silent" (p. 241). Socrates asks Glaucon: 
And what if sound echoed off the prison wall opposite them? When any of the passers-by spoke, don't you think they'd be bound to assume that the sound came from a passing shadow ${ }^{1}$ (p. 241)

To this somewhat rhetorical question, Glaucon answers, "I am absolutely certain of it" (p. 241). In the remaining text, Plato does not make any further hints to sound or to listening. Espinet (2016) asks: Why is listening [hören] - and with it audibility [das Hörbare] - left behind in the cave? On this point, Plato keeps secret the possibility of listening (pp. 7-8). Is it because Plato senses that an audial metaphor is unsuitable for his purposes and that shadows and echoes are fundamentally different phenomena?

Let us examine thoroughly the voices and the echoes in the cave. As Socrates describes at the beginning, since childhood, the prisoners' legs and necks have been tied up "in a way which keeps them in one place and allows them to look only straight ahead, but not to turn their heads" (Plato, 1993, p. 240). Socrates does not mention explicitly the prisoners' ability to listen, even though he refers to the sounds behind the prisoners. Socrates introduces the echo as a parallel to the shadow. Just as the shadow is thrown onto the wall and perceived by the spectators, so is the sound reverberated from the wall to the listeners. With his question to Glaucon, it seems that Socrates seeks confirmation of his attempt to double the metaphor.

Before comparing more in-depth the experience of hearing an echo to the experience of seeing a shadow, I will briefly dwell on the meaning of a metaphor. ${ }^{2}$ A metaphor equates two things, not because the comparison is valid in the sense that the two things are identical, but for the case of illustrating an idea or explaining a thought. If a person is 'quiet as a mouse,' it is not literally true; the comparison aims at describing the person's character using the mouse's character as support. To understand the meaning of a metaphor, we have to know and be acquainted with the related object. If I have never seen or heard about a mouse, of course, the metaphor makes no sense. Also in scientific argumentation, we find extensive use of metaphors. In the Origin of Species, Darwin uses artificial selection to explain natural selection, the central idea of his work. For example, when he claims, "man can do much by his powers of artificial selection" (Darwin, 1985, p. 153), it is as a comparison to the superior powers of Nature's form of selection. As a help to understand what natural selection is about, he describes it as the "opposite" of artificial selection, breeding of plants and domestication of animals. Darwin can be quite sure that the reader knows the meaning of artificial, manconducted selection.

Plato's light-shadow metaphor makes sense because the visual image of the shadows and the description of the prisoners' one-direction sight on the back wall are in accordance with our visual experience. However, his attempt to draw an audial parallel fails, I argue, because the description does not correspond to our audial experience. Let me expand on this argument from five perspectives:

First, as listeners, we can direct our hearing to the back. Because the prisoners do not have eyes that can see backward, they see neither the light from the fire nor the objects throwing the shadows. However, for the prisoners chained to the ground, with their heads

\footnotetext{
${ }^{1}$ In Plato (1992, p. 187), there is a different translation of the original text: "And what if their prison also had an echo from the wall facing them? Don't you think they'd believe that the shadows passing in front of them were talking whenever one of the carriers passing along the wall was doing so?" In Heidegger's (2002) translation of the original text, the audial description is not an echo, but a reflected sound: „And if the wall of the prison opposite them reflected sound..." (p. 19).

2 According to Britannica Academic (2018), a metaphor is "a figure of speech in which a word or phrase denoting one kind of object or idea is used in place of another to suggest a similarity between them," whereas an allegory is "a story in which the characters and events are symbols expressing truths about human life." These slightly different meanings of metaphor and allegory I will not discuss further.
} 
facing towards the wall, it should be possible for them to hear the persons in the back without turning their heads. They listen to them talk as the wanderers move from one side to the other, and they are perhaps even able to distinguish the meaning of their talk. Thus, the ears of the prisoners might give a precise rendering of the moving people in the background.

Second, compared to the shadow on the wall that replaces the exposed object, an echo thrown back from the wall does not replace the initial sound; it repeats it. If I play a regular drumbeat like "ka, ka, ka, ka..." loudly against a wall, I hear - standing in the correct position - both the sound source and its echo. ${ }^{3}$ I hear "kaga, kaga, kaga, kaga..." where "ka" is the initial drum sound and "ga" its echo. ${ }^{4}$ I also hear "ga" slightly after "ka" and "ga" as slightly softer than "ka." This is due to the laws of acoustics: An echo is a sound that has traveled a longer distance to come to my ears compared to the direct heard sound, which is why my ears hear the echo slightly after the initial sound. On its journey, the sound loses a bit of its initial energy, which is why my ears hear the echo as a slightly softer sound compared to the initial sound.

Third, when a three-dimensional object is exposed to light so that we can see it as a shadow, it is reduced to a two-dimensional image. When we see a circle-round shadow on the wall, we cannot but guess what object is exposed; it might be a plate, a cup, a cone, or a whole range of other objects. This reduction is, of course, the central idea in Plato's allegory; the prisoners experience the world in a reduced form, with fewer dimensions compared to the world as it "really" is. In the echo experience, however, we hear the same sound twice. In the visual experience, what our eyes see as a shadow is a two-dimensional reduction of an object. In the audial experience, in contrast, our ears hear a twin pair of sounds. This is, of course, true only for short sounds. When for instance a whole sentence is yelled against a wall, only the very last word - or part of the word - is heard. It is in this phenomenon that we find the etymological origin of the word: In Greek mythology, Echo was the mountain nymph who Hera punished so that she was able to repeat only the last words spoken to her. ${ }^{5}$

Fourth, to be able to experience a true echo, a single reflection of the sound, the initial sound must have sufficient volume. It is not enough merely to make a sound or sing a tone against a wall; the sound has to have enough energy to bounce back from the wall to be recognized as an echo. In this regard, the kinship between a visual and an audial phenomenon is obvious; producing a shadow also requires a certain amount of light. However, the shadow does not have to "compete" with the visual image of the object, as the echo "competes" with the initial sound. When listening to the carriers passing, their sounds would probably not be loud enough to be registered as a true echo at all. If the talking had been loud enough, the prisoners would perhaps have heard both sound source (from behind) and its echoes (from the opposite wall). In any case, they would, first of all, hear sounds coming from the back and not the ones coming from the wall in front of them.

Finally, I doubt that the prisoners at all would experience that "the sound came from a passing shadow" (Plato, 1993, p. 241). To experience an echo the way Socrates suggests, one should not enter a cave, but seek a suitable surface in an open landscape. In the cave, if not of gigantic proportions, the sounds reverberate from all surfaces, not only from the opposite

\footnotetext{
${ }^{3}$ In order to hear a true echo, the original sound needs to be delayed at least 1/10 of a second. Because velocity of sound is ca $340 \mathrm{~m} / \mathrm{s}$, the distance from the listener located at the sound source to the reflecting surface should be at least 17-18 meters, giving a total distance of ca 35 meters from sound source to the ear.

4 Pronounce "kaga" with "ka" and "ga" as fast as possible after one another, with a tiny pause to the next "kaga."

${ }^{5}$ According to Ovid, the mountain nymph Echo offended the goddess Hera by keeping her in conversation, thus preventing her from spying on one of Zeus' amours. To punish Echo, Hera deprived her of speech, except for the ability to repeat the last words of another. Echo's hopeless love for Narcissus, who fell in love with his own image, made her fade away until all that was left of her was her voice (Britannica Academic, 2019, keyword "Echo").
} 
wall. Whereas a dark cave is a perfect place to experience a shadow on the wall, the cave environment instead and resonates the sound in multiple ways.

Putting shadow and echo on one level makes sense, scientifically speaking, because both light and sound are waves that the wall throws back on the persons sitting in front of it. However, we do not experience these throwbacks as waves; our eyes see them as shadows and visual forms, and our ears hear them as sounds and echoes. Listening is fundamentally different from seeing, and therefore the two forms of sense experience cannot be equated the way that Plato suggests. The visual metaphor very well suits Plato's purpose whereas an audial metaphor does not.

\section{Representations and "the Real"}

As I have stated above, the cave allegory sounds differently when applied to audial experience. The lack of conformity between an audial experience and a visual one gives rise to some explorative questions: Are there more aspects to an audial reading of Plato's cave allegory than merely to state that Socrates' attempt to strengthen the shadow metaphor by adding echoes to it failed? Does an audial reading of the cave allegory reveal new aspects of the relation between reality and represented reality?

In an elaboration of the cave allegory, Corinne P. Sze (1977) discusses listening and its relation to sight in Plato's Republic as a whole. When Plato in the allegory includes sound and echo, he has in mind the theatre "where poetic imitation takes place exploiting the illusions of both sight and sound" (p. 132). The prisoners' situation resembles the one in the theatre, "dominated by the sights and sounds ... and more generally by the poetic and oral tradition" (p. 132). When Plato introduces sound, so Sze, "[i]ts purpose is not to "merely complete the picture': it has symbolic reference to the acoustic experience of the audience" (p. 133). On this background, we can easily understand Socrates' question to Glaucon, whether he believes that the prisoners would "be bound to assume that the sound came from a passing shadow" (Plato, 1993, p. 241). Apparently, Socrates appeals to Glaucon's experience as a theatergoer.

The shadow metaphor is probably also motivated by the fact that Plato's Greece was familiar with puppet shadow shows (Guthrie, 1977, p. 518). Here, the audience only sees the shadows of the puppets thrown on a screen where light and puppets are behind the screen. In his thought experiment, Plato creates a situation where light and sound come together and are perceived as shadows and echoes. In this sense, Plato's cave has become a reality in the cinema (Marsden, 2014). The parallel to the theatre is understandable because the moving and sounding shadows associate with actors on a stage. In the imaginary cave, however, Plato presupposes the sound to come from the front of the prisoners, which is not the case. If a theatre were the setting, then both sight and sound would come from the audience's front. Thus, the "acoustic experience of the audience" (Sze, 1997, p. 133) is fundamentally different in a theatre performance compared to the strange situation in the cave.

To Plato and the ancient Greeks, music was paramount among the characteristics of the civilized community (Bowman, 1998). Music was an essential part of education, for both moral and rational reasons. Music was taken very seriously, "[be]cause of its potency, and because it was an inextricable part of society, education, and practically all facets of life" (p. 20). To the Greek mind, music, poetry, drama, as well as dance were practically inseparable from one another. Plato tended, however, to downplay the significance of sensing and sensuous experience in favour of reason and the rational mind. That which appears to the senses is transitory and of a distinctly lower order than the idea. Thus, "music's educational value had little to do with sounds heard, or music made" (p. 25). Music's value was not grounded in appreciating it as sounding appearance. With reference to Pythagoras, music's 
real significance was to be found in its mathematical nature. Against this background, it is understandable that Plato lets the prisoner raise from the captive deep of the cave into the light of ideas. It is easier to understand why Plato leaves the cave as a place of sense experiences. It does not explain, however, the apparent differences between seeing and hearing in the cave. ${ }^{6}$

In Time and Being, Martin Heidegger (1962) develops the idea of our complex and sensory engagement with the world and the position of the person within it. Our senses do not read some objectively given world. Rather, the fact that we sensorially perceive the world's on-going, is an evidence of our already Being-in-the-world. Among the senses, listening holds a prominent position in Time and Being. Heidegger discusses the audial experience by contrasting hearing with hearkening (Horchen): "Hearkening is phenomenally still more primordial than what is defined 'in the first instance' as 'hearing' in psychology - the sensing of tones and the perception of sounds" (p. 207). Human speech is a special kind of sound because of its immediate claim for intelligibility. Listening to speech means to expect and seek meaning; it is even the hearkening waiting for meaning that always also can fail to appear (Espinet, 2014, p. 102). Against this backdrop of phenomenological exploration of forms of listening, it is noteworthy that Heidegger in his later published Essence of Truth (Heidegger, 2002) interprets Plato's cave allegory entirely in visual terms. ${ }^{7}$ Admittedly, he invites us to "place ourselves once again in the situation of the prisoners, which basically is not difficult to do" (p. 23), but merely as seeing, not as listening, persons. He interprets the cave allegory as a transition in four stages: the hidden in the cave (the shadows), the liberation of man within the cave, the genuine liberation of man to the primordial light, and the freed prisoner's return to the cave. Heidegger elaborates carefully the occurrence of truth, understanding the allegory "as a clue to the essence of unhiddenness" (p. 17). Is his ignoring of sound in the cave due to the uselessness of the audial metaphor?

Sze (1977) dwells at the turning of the head of the prisoner, to see the fire in the cave (Heidegger's second stage). This is the moment when one of the prisoners is freed "and is suddenly made to stand up, to turn his head and walk, and to look towards the firelight" (Plato, 1993, p. 241). The freed prisoner's turning around is guided by sight, not by sound. He can now view the rest of the cave, the fire and the people passing by. It is all new to him because it is seen for the first time. If Plato had stuck to his hinting of an additional audial experience, the prisoner would, after having turned around, of course, hear the same noises and sounds. Now he would be able to add a visual image to the sounds he had heard all along. The prisoner would see the fire of which he merely had heard its crackle. And he would admittedly be able to watch the persons passing by who's voices had been long familiar to him. As "some of the people talk" (p. 241), the prisoner would hear their conversation as meaningful talk or as undistinguishable muttering.

With reference to the acoustics in Plato's cave, Alan Marsden (2014) investigates the objective nature of sound. When comparing a shadow and a shadow-casting object they are, he claims, different kinds of thing, "but a sound and its echo are both sounds" (p. 42). I would modify this claim slightly. The visual experience of the object casting the shadow is different from the experience of the shadow itself. However, the audial experience of the sounding objects consists of two intimately related, though different sensations: the original sound and its echo. I agree, though, that for the listener "there is no aural equivalent of the change in perception from object to shadow" (p. 42). This, again, emphasizes the profound differences between listening and seeing.

\footnotetext{
${ }^{6}$ Even though Bowman (1998) refers to the cave allegory, it is without mentioning the cave's sound or discussing the allegory's audial potential.

${ }^{7}$ Vom Wesen der Wahrheit was published in 1930, three years after Sein und Zeit.
} 
The freed prisoner perceives aspects of the enlightened object as richer and more real, for example, when it comes to colour and three-dimensional form. He now can see the actual persons of which he only knew their shadows. But is there a "real object," aurally speaking? Marsden compares the original and the reverberated sound and concludes, "there would be little to suggest that one sound was more real than the other" (p. 42). He expands on the notion of sounds as musical objects where a sound is objectified and treated as a pure, acoustic phenomenon independent of meaning. If we, however, remain in the cave and examine it further as a space of sounds, it seems obvious that the fettered prisoners do not hear sound objects; they hear people moving and speaking. Human speech is indeed also sound, acoustically speaking, but it demands of the listener's immediate intelligibility. Listening as world bonding is obvious, Heidegger explicates, in those cases where human speech is indistinct or in a foreign language. Here, "what we proximally hear is unintelligible words, and not a multiplicity of tone-data (italics original)" (Heidegger, 1962, p. 207). Even if the prisoners could not understand exactly what the passing persons were talking about, they would most probably recognize the sounds as speech. Aurally speaking, the talking and moving persons do not become more "real" for the freed prisoner just because he has turned his face toward them.

As already stated, Plato's intention with the allegory was to depict the relation between reality and its shades. What is the real world and what do we believe to be the real world? To Plato, all particular things in the world are in some way or the other imitations or shadows of the "highest reality." For Plato:

... [t]he empirical world of the senses is 'real'; yet, because the senses alone cannot provide true knowledge, their significance pales in comparison to the 'light' (note the visual metaphor) of the rational realm. The highest reality, the most real, is ideal. (Bowman, 1998, p. 28)

Plato lets us understand that the shadows of the moving persons behind the prisoners are visual representations of the carriers. In his analysis of the cave allegory, Heidegger (2002) notes that "[t]he prisoners do indeed see the shadows but not as shadows of something" and that they "have no relationship to light as light, for neither do they see the fire that casts the light (italics original)" (p. 20). For the prisoners, both light source and lightened object are hidden. Thus, the shadows appear for them as the reality and not as representations of the reality. This might explain why they do not believe the returned prisoner who, after having been outside, talks about "the actual things themselves" (Plato, 1993, p. 242). Only the returned prisoner recognizes the shadows as reduced representations of the carriers behind the fettered prisoners.

Now, if shadows are two-dimensional representations of three-dimension objects, then what are echoes? Do they represent something at all? To re-present something is, literally speaking, "to present again or anew." Etymologically, to represent is "to bring to mind by description," from Latin repraesentare "make present, set in view, show." A shadow makes present a reduced rendition of the exposed object. Ten different shadows of a lighted object might make it possible for the spectator to recognize whether it is a plate, a cup, a cone, or some other objects. However, some aspects of the object are definitively lost. The spectators will never know that the cone has a deep blue colour, that the plate has ornamental figures pained on it, and that the cup is made of the finest china. An echo, on the other hand, is a reverberation of the original sound. The echo makes present the original sound without losses

\footnotetext{
${ }^{8}$ According to Britannica Academic (2018), keyword "represent."

9 According to Online Etymology Dictionary (2018), keyword "represent."
} 
of dimension (even though it appears as a softer sound). When comparing sound to sight, I find a higher concordance between the echo and the visual image reflected from a mirror. Compared to a mirror image, a shadow is a poor visual reproduction.

In Plato's (1993) allegory, it is only outside of the cave, in the warm light of the sun, that the freed prisoner is able "to see the actual things themselves" (p. 242). However, first, the prisoner has to adjust his eyesight to the bright, illuminated environment, "because his eyes would be overwhelmed by the sun's beams" (p. 242). Now, would not also the prisoner have to adjust his ears to the new environment? The prisoner's ears would eventually become attuned to the "sonorous field" (Howard, 2018, p. 31) of the world. The prisoners down in the cave do perfectly well hear the person passing behind them, even though they do not hear the echoes. As I noted in my reflection on the sounds in the cave, to hear an echo the way Socrates suggests it is best to seek a suitable surface in an open landscape. Compared to attending to the cacophony of the sounding landscape, hearing a true echo needs a rather artificial setting. Out in the open, the "real" world speaks to us in hundred languages. Listening to the world as speech implies to become aware of the rich soundscape that surrounds the listener and experience "the many articulations of the absence of noise" (p. 31).

My elaborations show some profound differences between echoes and shadows and between sound and sight. Whereas the shadows projected onto the wall represent external features of the enlightened objects (the persons behind the prisoners), the echoes bring back to the prisoners sounds of processes and on-going. To listen means to listen to events. For Dewey (2005), the eye is the sense of the distance, whereas the ear "brings home to us changes as changes" (p. 245). Our ears reveal the familiar world regarding closeness and change:

Sounds come from outside the body, but sound itself is near, intimate; it is an excitation of the organism; we feel the clash of vibrations throughout our whole body. Sound stimulates directly to immediate change because it reports a change (italics original). (p. 246)

Sound reveals different aspects of "the real" compared to sight. It is thus not surprising that it is hard to replace an audial with a visual metaphor. Perhaps it is easier to find a kinship between seeing and listening when we compare them in a learning environment?

\section{Listening and Learning}

Plato makes an educational point at the very start of the allegory. Socrates introduces to Glaucon "a situation which you can use as an analogy for the human condition - for our education or lack of it" (Plato, 1993, p. 240). Plato has in mind two things: that education allows us to see things as they truly are, and that some enlightened persons - i.e., the philosophers - comprehend reality more truly than those who dwell in delusion. Before elaborating further on the educational aspects of the cave allegory, I first discuss the phenomenological critique of constructivism in science education and phenomenology's intention of refining the skills of attentiveness.

With reference to Edmund Husserl's phenomenological critique of modern science in The Crisis of European Sciences, Harvey (1989) develops the notion of the ontological reversal. The idea refers to an ontological position where abstract models from science are considered as more real than the everyday reality itself. The scientific objectivities take on a life of their own; they "seem to stand disconnected over and above the fluctuating appearances of daily life while explaining these appearances (italics original)" (p. 63). 
Cognitive achievements are no longer experience-based, and the idea of nature appears as a mere mathematical manifold:

Indeed, even for those who are repulsed by the natural scientific world-view, the pregiven world is given as mathematically determinable in principle; it is given as the physico-material totality of what is. And it is implicitly believed, though rarely professed, that after the world is determined in this fashion, nothing is left over (italics original). (p. 65)

It would be an error to conclude that Husserl was critical against natural science or mathematics per se. He was himself a mathematician who delighted in theory, especially in axiomatics (Heelan, 1987). What Husserl criticized about the European sciences, was not the use of mathematical models, "but that, (generally) led by a false metaphysics, it (generally) mistook them for reality" (p. 370). His critique implies a re-turning toward human life-world experience as it appears prior to conceptualizations.

The ontological reversal forms an underlying assumption among science teachers when they use lifeworld phenomena as examples of scientific knowledge and as a means to illustrate abstract models. As long as theoretical, scientific knowledge is taken as the real cause behind everyday experiences, knowledge that by its nature is to be conceptually understood and explained, teachers tend to put less emphasis on students' own perception and experience (Dahlin, Østergaard \& Hugo, 2009). Children's rich experiences of natural phenomena are devalued and forgotten in the teaching about science and nature. Dahlin (2001) refers to such disregard as cognitivism: students' experience and behaviour are interpreted as an expression of a lack of concepts as a conceptual deficiency.

In constructivism, representations are "recognizable expressions such as verbal language, graphs, images, tables, drawings, diagrams, and so on" (Knain, 2015, p. 61). These are all visual expressions. The character of the investigated object or topic emerges when several forms of representations are put in a multimodal relation. An implicit assumption is that the nearest we can approach the character of "the things" is by adding sufficient representations of it. The various modes "are resources for meaning making in representations" (p. 61). For students in science class, the pitfall is "that word and object are (con)fused, as if they were the same thing, with a consequent loss of understanding both of the role of the signifier in the construction of meaning and of the possibility of a plurality of meanings and points of view" (Camino \& Dodman, 2009, p. 76). A confusion of word and object, I claim, also influences the understanding of the character of the explored object itself. The phenomenological critique of constructivism addresses the problem of mistaking the derived for the original (Dahlin, 2001; Østergaard, Dahlin \& Hugo, 2008). Considering the underground cave, the prisoners living there "are those who in a dream state mistake the semblance for the thing itself" (Sze, 1977, p. 133). If different shadows of an object comply with the various representations, then an addition of its representations will per se never give a complete rendition of the object, merely a more or less faithful reproduction. In an educational setting, it is a problem for students if their teachers mistake the semblance for the real. In addition, a confusion of reality with represented reality might cause problems when it comes to students' active involvement in everyday life. How are students supposed to develop a caring and personal involvement in the world if they are taught that "world" is merely composed of its representational imprints?

According to van Manen (1997), phenomenology is the study of lived experience as "it attempts to gain insightful descriptions of the way we experience the world prereflectively" (p. 9). In this particular case of the sounds in the cave, my lived experience is a heard experience. It is, however, somewhat problematic to claim that my description of the 
sounds in the cave is an account of pre-reflective experiences. The phenomenologist points toward experience as we live it, not as we describe it or theorize it. But how do I bring the audial experience into a verbal, reflected expression? The moment I put words to it, it is strictly speaking no longer a pre-reflected experience, but a textual representation. With an openness to phenomena in their pre-conceptual appearances, the question of the relation between the pre-representational and the representational levels emerges.

The attempt to equate shadow and echo motivates me to dwell on the dominance of visual representations compared to audial ones. In Reason and Resonance, Erlmann (2010) develops the idea of aurality as a hidden trait in the development of modern thought. He claims that the acoustic and physiological phenomenon of resonance has played a constitutive role in the history of aurality and rationality. He attempts to broaden the complex relationships between understanding and resonance and hearing and meaning-making. Which link is there between visuality and the development of modern thought? How does, on the other hand, aurality possibly influence our way of thinking and perceiving the world? I find his "elaboration of the concept of modernity through hearing" (p. 15) both ambiguous and appealing because here Erlmann accentuates the idea of a genuine aurality emerging from attentive listening. Erlmann's discussion of aurality vs. visuality fits very well to Plato's cave as a place for sound and sight, even though he does not mention the allegory explicitly.

Both our language and reasoning are marked by visuality. To have a bright idea or to take part in a group reflection are typical characterizations that we find in our language. When I apply audial expressions to its content of meaning, it immediately sounds differently: To have a sonorous or ringing idea or to take part in a group resonance. The constructivists' point is that we always have to rely on the representations, either as text or as other visual expressions. As written language is of paramount significance in education (Knain, 2015), teachers tend to accentuate visuality and underestimate aurality. The significance of Plato's cave allegory should be evaluated in relation to modern, scientific thought characterised by a visual-spatial language. With the help of Plato's allegory, the light-shadow polarity has become the Urbild of represented reality. At the same time, a visually oriented culture of ideas repeatedly confirms Plato's cave allegory as its central metaphor.

Phenomenology provides both a theoretical perspective and a method. As a perspective, it represents a fruitful angle for discussing historical and contemporary lifeworld phenomena. A phenomenological perspective allows for broadness of aspects of the explored topic to emerge. As a method, phenomenology is a call for exploring lifeworld by using one's senses carefully as entry into analysis and conceptualizations. Phenomenology strives "to find out what a certain phenomenon means and how it is experienced" (van Manen, 1997, p. 29). Phenomenology both values and presupposes one's own experiences as a basis for reflection. Hence, to do phenomenology is to employ skills and competencies when exploring lived experience. When applied to science education, phenomenology appears as most fruitfully when it is done, that is, when it is turned into actual efforts in class for promoting learning (Østergaard, Dahlin \& Hugo, 2008). The core skill in a phenomenology of audial experience is, of course, the ability of listening. Thus, its central educational task is to train and refine the skill of attentive listening. Nature speaks in hundred languages, Dahlin (2001) claims, "but we have become deaf to ninety-nine of them" (p. 454). If being in the world means being through our senses and bodies, then there is a need for an awareness of how we are in the world with our bodily senses and how teachers can promote their students' sensuous abilities (Østergaard, 2017).

For the last 14 years, I have taught a phenomenon-based teaching unit at our science teacher education program called "Sound and sensibility." Here, sound phenomena form gravitational points for introducing scientific and everyday sound concepts (Østergaard \& Dahlin, 2009). Audial experience ties together sound phenomenon and sound concepts. The 
purpose is twofold: to ground concepts (i.e., frequency) in experience (i.e., sounds of ringing crystal glasses) and to refine teacher students' listening skills. During the last years, I have gradually shifted focus from sound and strategies to explain sound to attentive listening and measures to promote listening skills. In current science teaching, teachers seem to take sensing and perception for granted. Thus, the skills are rarely taught systematically. This is in contrast to the schooling of observation skills in art education and listening skills in music education (Østergaard, 2017; 2019). ${ }^{10}$ An explicit emphasis on sense experience - a central claim of phenomenon-based science education - aims at balancing the major focus on scientific conceptualization and modelling in today's science class. Practicing skills in science class is in line with the intention of restoring the value of lifeworld experience and sense perception (Dahlin, Østergaard \& Hugo, 2009) as well as the pedagogical project of reanimating the world (Howard, 2018, p. 34).

To promote the skills of listening, we first have to differentiate between forms of listening. Normally we think of hearing as receiving sound with the ears, whereas listening is a practice of audial engagement. Whereas hearing is one of our physical senses, listening requires focus and attention; it requires "active engagement with attention" (Oliveros, 2005, p. xxi). If listening with focal attention is limited to an object of attention, global attention is more diffuse, embracing "the whole of the space/time continuum of sound" (p. 13). We continually practice skills of listening on a broad spectrum of variation, from accidental overhearing to the point of attentive hearkening. Between these extremes, we find a variety of listening forms: Intently listening implies a form of focused attentiveness, whereas eavesdropping is a form of listening-in, to the point of closer listening (Østergaard, 2019). It is obvious that training listening skills will have to take into account the diversity of listening forms as well as the intentions of listening. After all, there is a difference between listening to a science teacher explaining the wave structure of a tone and listening to Händel's Messiah. It is tempting to expect that the skills of musical listening are transferable to other contexts. However, listening with a discerning ear to complex musical structures in the concert hall is not per se applicable to other listening situations, for example in physic class' acoustic lessons. I would still argue that the fact that musicians and music educators are trained in listening implies both a long educational tradition and an aesthetic potential that can be shared with other school subjects.

Exploring the echo phenomenon in the cave is both motivated and marked by my musical ears. Sound interest me, not only the particular kind of sound that we call music. My sonic interest brought me into the cave to listen to its sounds and resonances. As a composer, I employ my listening in a distinct manner; my attentive listening is specific because of its intentionality. The fact that I listen is a prerequisite to developing an audial reflective understanding of the cave as a learning space. For composers, however, the experience of musical listening and articulation is not automatically a good prerequisite for hearing. I am even not sure that musical ears are particularly fitted for hearing anything else than music (Østergaard, 2019). Thus, my listening to Plato's sounding shadows has been guided by a sincere attempt to apply musical listening to an actual, situated sound experience.

Is the cave a suitable learning environment at all? Plato (1993) explicitly refers to the cave narrative as "an analogy for human condition" (p. 240). Its darkness and shape of a cavernous cell suits very well the metaphor of shadows. However, it does not appear to be the right place for listening for echoes or promoting audial skills. Still, an elaboration on the sounds in the cave proves to be fruitful in an educational sense - if not a useful metaphor for

\footnotetext{
${ }^{10}$ In Østergaard (2017), I discuss sense experience as aesthetic experience, a comparison that enables us to recognize the potential kinship of scientific and artistic work in education.
} 
Plato's purpose. It sharpens the differences and complementarities of audial and visual experiences.

\section{Conclusion}

This reconsideration of the cave allegory is based on me employing my listening ability in the situation described by Plato. The arguments I bring forth are thus experiential-based. My initial question was not what the inherent meaning of Plato's shadow metaphor is. Instead, I asked myself: If put in a position in a cave, as the one Plato describes, what exactly would I hear? After having described and analyzed what my ears hear, I find it hard to support an equation of the visual and the aural metaphor. However, there are no clear-cut differences between experiencing, putting-words-to and analyzing. In a phenomenology of audial experience, the phenomenological content analysis builds on a thorough description. Further, a phenomenological description presupposes a skill of pre-conceptual attentiveness: the wordless ability to listen attentively. All in all, there are different skills at work to produce a phenomenologically rich and experientially sound account of the cave situation.

Why did Plato keep "secret the possibility of listening" (Espinet, 2016, p. 8) in the cave? I guess we will never have definite answers to this question. There are, however, several possible responses. First, Plato did not seem to have very high thoughts about poetry, music, and drama (Guthrie, 1977). His interest was more related to music as mathematical expression than music as sensuous experience (Bowman, 1998). This might have been a reason for him to ignore aurality. Second, the obvious similarity between the cave wall and the theatre stage hindered him from realizing that in the cave, sound comes both from behind (the original sound) and from the front (reverberations as echoes). Third, Plato downplays sensing and sense observations for the benefit of reason. In contrast to Aristotle, whose intention was to put observation at the core of knowledge acquisition, Plato relied fully on the power of thought to come to an understanding of the world of ideas. No wonder his interest in listening and sound is somewhat inadequate. Finally, Plato might have sensed that the echoshadow comparison essentially failed. When emphasizing daylight and the primordial world of enlightening ideas, he "leaves quasi listening back on the darkness of the cave" (Espinet, 2016, p. 66).

During my visits to the cave, many questions have emerged. Of these, several remain unanswered in this article. If phenomenology is the study of lifeworld phenomena as "we experience the world pre-reflectively, without taxonomizing, classifying, or abstracting it" (van Manen, 1997, p. 9), then what exactly is a pre-reflective, non-cognitive aural sensation? How can I answer the question without employing abstract, reflective language? Bound as we are of the written word, it seems challenging to sustain pure experience when the experience is transcribed as text. Further, I have merely touched upon the question of the ontology of the sounding world and how it shows itself aurally. What is a sonic representation and what is it supposed to represent? If an aural phenomenon is more than the sum of its sonic representations, then what precisely is this "more than," that which is beyond the representations? In my further research, I also intend to explore harkening and attentive listening as part-taking in the world with its two intimately related dimensions. On the one hand, listening means to stretch out to the world, to seek its multiple voices actively. On the other hand, listening is receptively to let the world sound, to be open to it sonorous expressions. There is, as Blenkinsop and Piersol (2013) claim, limited literature with regard to listening to the natural world within education and the natural world as "an active, subjective, agential speaker of its own accord" (p. 44). What is the Aufforderingscharakter of the sonic world, that is, how does the world invite our ears to search its aural expressions? 
The focus of my exploration is the point where the listening's active and receptive dimensions merge.

Listening is an aesthetic practice that grounds us in the world. Listening is both world participating and world receiving. Listening embraces both activeness and receptiveness. Peter Höeg's (2006) novel The Quiet Girl is about a person whose ability to listen is exceptionally well developed. At one point in the story, the protagonist is outside, thinking back on what his girlfriend once had told him about sounds:

The night had been quiet. When frozen, all things become brittle and silent. Stine had explained to him why, all sound-reflecting surfaces become hard and at once elastic, like ice and glass. Therefore, the Koan of the frost night: Everything can be heard, and there is no sound. (p. 134)

It is one of the beautiful paradoxes of listening; that listening to silence reveals more than a mere absence of sound. Hearing everything and at the same time hearing nothing is a riddlelike question. It is as a Koan not designed to be answered logically - but perhaps phenomenologically.

\section{References}

Blenkinsop. S, \& Piersol, L. (2013). Listening to the literal: Orientations towards how nature communicates. Phenomenology \& Practice, 7(2), 41-60.

Bowman, W. D. (1998). Philosophical Perspectives on Music. New York/Oxford: Oxford University Press.

Britannica Academic (2018). Online Encyclopaedia. Retrieved 8. October 2018 from https://academic.eb.com/levels/collegiate

Britannica Academic (2019). Online Encyclopaedia. Retrieved 20. March 2019 from https://academic.eb.com/levels/collegiate

Camino, E., \& Dodman, M. (2009). Language and Science. In D. Gray, L. Colucci-Gray \& E. Camino (Eds.). Science, society and sustainability. Education and empowerment for an uncertain world (71-96). New York/London: Routledge.

Dahlin, B. (2001). The primacy of cognition — or of perception? A phenomenological critique of the theoretical bases of science education. Science \& Education, 10, 453-475.

Dahlin, B., Østergaard, E., \& Hugo, A. (2009). An argument for reversing the bases of science education - a phenomenological alternative to cognitionism. NorDiNa, 5(2), 201-215.

Darwin, C. (1985). On the Origin of Species by Means of Natural Selection, or the Preservation of Favoured Races in the Struggle for Life. Reprint of the first edition. London: Penguin Classics.

Dewey, J. (2005). Art as experience. London: Penguin Books.

Erlmann, V. (2010). Reason and resonance. A history of modern aurality. New York: Zone Books.

Espinet, D. (2016). Die Phänomenologie des Hörens. Tübingen: Mohr Siebeck.

Guthrie, W. K. C. (1977). A history of Greek philosophy. Volume IV. Cambridge/London/New York: Cambridge University Press.

Harvey, C. W. (1989). Husserl's phenomenology and the foundations of natural science. Athens, GA: Ohio University Press.

Heelan, P. A. (1987). Husserl's later philosophy of natural science. Philosophy of Science, 54(3), 368-390. 
Heidegger, M. (1962). Being and time (J. Macquarrie \& E. Robinson, Trans.). Oxford UK: Basil Blackwell.

Heidegger, M. (2002). The essence of truth. On Plato's cave allegory and Theaetetus (T. Sadler, Trans.). New York/London: Continuum.

Howard, P. (2018). "Deeper than even the grain goes": Attending to sound as pedagogical practice in Alphonso Lingis's The Murmur of the World. Phenomenology \& Practice, 12(2), 28-36.

Höeg, P. (2006). Den stille piken (K. Johansen, Trans.). Oslo: Aschehoug.

Knain, E. (2015). Scientific literacy for participation. Rotterdam, Boston, Taipei: Sense Publishers.

Marsden, A. (2014). Echoes in Plato's cave: Ontology of sound objects in computer music and analysis. In A. Georgaki \& G. Kouroupetroglou (Eds.), Proceedings $I C M C|S M C| 2014$, (41-46;14-20). Athens, Greece: Publisher.

Oliveros, P. (2005). Deep listening. A composer's sound practice. New York/Lincoln/Shanghai: iUniverse.

Online Etymology Dictionary (2018). Retrieved 18. October 2018 from www.etymonline.com/word/represent

Østergaard, E. (2017). Earth at rest. Aesthetic experience and students' grounding in science education. Science \& Education, 26, 557-581.

Østergaard, E. (2019). The attentive ear. Forthcoming in Journal of Aesthetic Education.

Østergaard, E., \& Dahlin, B. (2009). Sound and sensibility. Pre-service science teacher students bridging phenomena and concepts. In: Proceedings from 2009 NARST Annual International Conference. April 17 - 21, 2009, Garden Grove, CA, USA, p. 328 (full paper on conference CD-ROM).

Østergaard, E., Dahlin, B., \& Hugo, A. (2008). Doing phenomenology in science education: a research review. Studies in Science Education, 44(2), 93-121.

Plato (1992). Republic. (G. M. A. Grube, Trans.). Indianapolis/Cambridge: Hackett Publ. Comp.

Plato (1993). Republic. (R. Waterfield, Trans.). Oxford/New York: Oxford University Press.

Sze, C. P. (1977). EIKA $\Sigma I A$ and $\Pi I \Sigma T I E$ in Plato's Cave Allegory. The Classical Quarterly, 27(1), 127-138.

van Manen, M. (1997). Researching lived experience. Human science for an action sensitive pedagogy. London, Ontario: The Althouse Press. 